\title{
Review \\ The Recent Development of the Surgical Treatment for Hepatocellular Carcinoma
}

\author{
Masao Nakajima ${ }^{1}$, Yukio Tokumitsu ${ }^{1}$, Yoshitaro Shindo ${ }^{1}$, Hiroto Matsui ${ }^{1}$, Satoshi Matsukuma ${ }^{1}$, Michihisa Iida ${ }^{1}$, \\ Nobuaki Suzuki ${ }^{1}$, Shigeru Takeda ${ }^{1}$, Tatsuya Ioka ${ }^{2}$ and Hiroaki Nagano ${ }^{1, *}$ \\ 1 Department of Gastroenterological, Breast and Endocrine Surgery, Yamaguchi University Graduate School of \\ Medicine, Ube 755-8505, Japan; masao-y@yamaguchi-u.ac.jp (M.N.); yt790604@yamaguchi-u.ac.jp (Y.T.); \\ y.shindo@yamaguchi-u.ac.jp (Y.S.); matsui-h@yamaguchi-u.ac.jp (H.M.); smatsu@yamaguchi-u.ac.jp (S.M.); \\ miida@yamaguchi-u.ac.jp (M.I.); nobusuzu@yamaguchi-u.ac.jp (N.S.); shigerut@yamaguchi-u.ac.jp (S.T.) \\ 2 Oncology Center, Yamaguchi University Hospital, Ube 755-8505, Japan; ioka64@@yamaguchi-u.ac.jp \\ * Correspondence: hnagano@yamaguchi-u.ac.jp; Tel.: +81-836-22-2264; Fax: +81-836-22-2263
}

check for updates

Citation: Nakajima, M.; Tokumitsu, Y.; Shindo, Y.; Matsui, H.; Matsukuma, S.; Iida, M.; Suzuki, N.; Takeda, S.; Ioka, T.; Nagano, H. The Recent Development of the Surgical Treatment for Hepatocellular Carcinoma. Appl. Sci. 2021, 11, 2023. https://doi.org/10.3390/app 11052023

Academic Editor: Francisco Arrebola

Received: 1 February 2021

Accepted: 20 February 2021

Published: 25 February 2021

Publisher's Note: MDPI stays neutral with regard to jurisdictional claims in published maps and institutional affiliations.

Copyright: (c) 2021 by the authors. Licensee MDPI, Basel, Switzerland. This article is an open access article distributed under the terms and conditions of the Creative Commons Attribution (CC BY) license (https:/ / creativecommons.org/licenses/by/ $4.0 /)$.

\begin{abstract}
The optimal treatment for hepatocellular carcinoma (HCC) should be selected based on tumor conditions, liver functional reserve, and performance status. Surgical treatment, such as liver resection and liver transplantation, is the most favorable treatment method; however, its indication criteria differ according to each country's guidelines. In Western countries, liver resection is indicated only for early-stage HCC patients with Barcelona-Clinic Liver Cancer staging classification (BCLC) 0/A. While in Asian countries, liver resection is one of the treatment options for advanced HCC, such as BCLC B/C. Recently, the treatment of HCC is about to enter a drastic transitional period. It started with the widespread use of minimally invasive surgery for HCC, followed by a high rate of hepatitis $C$ virus eradication with the advent of direct acting antivirals and developing a multidisciplinary treatment for highly advanced HCC. As a result, the importance of liver resection for HCC is increasing, and it is time to reconsider the criteria for selecting treatment methods for HCC patients. This article outlines current topics in the surgical treatment of HCC.
\end{abstract}

Keywords: hepatocellular carcinoma; surgical indication; portal vein tumor thrombus; hepatic vein tumor thrombus; multiple tumors; multidisciplinary treatment; laparoscopic liver resection; HCV; direct acting antivirals; liver transplantation

\section{Introduction}

Hepatocellular carcinoma (HCC) accounts for the majority of primary malignancy of the liver. It is the fifth most common cancer and is the second leading cause of cancerrelated death worldwide [1]. Liver resection and liver transplantation provide the most favorable outcomes for HCC [2]. However, the indications of liver resection for HCC differ significantly between Asian countries (Japan, Korea, China, Taiwan, etc.) and Western countries (Europe and the United States). In Asian countries, liver resection is recommended even for advanced HCC [3-5]. In contrast, in Western countries, liver resection is indicated only for a limited number of patients with early HCC, and liver transplantation is recommended for others [6,7]. Recently, the treatment of HCC is now at a turning point: the widespread use of minimally invasive surgery with the advancement of laparoscopic surgery, the high eradication rate of hepatitis $C$ virus (HCV) with the advent of direct antiviral agents (DAAs), and the development of multidisciplinary treatment, including surgical treatment, for highly advanced HCC that was previously incurable. In other words, the importance of liver resection in the treatment of HCC is gradually increasing with the development of new therapies and the accumulation of evidence. This article will discuss the current topics of the surgical treatments for HCC by comprehensive search of PubMed, EMBASE, and Cochrane library, taking into account the differences among countries and regions. 


\section{Surgical Indications for HCC}

The indications of liver resection for HCC depends on the liver functional reserve and biological features of the tumor. The first prerequisite is maintained liver function. Many guidelines require Eastern Cooperative Oncology Group performance status 0-1 and Child-pugh A/B as surgical indications [4-6]. Among them, the European Association for the Study of the Liver (EASL) and the European Organization for Research and Treatment of Cancer (EORTC) guidelines state that only patients with PS0, Child-Pugh A, and no ascites are eligible for liver resection [7]. Second, the indications for liver resection, based on tumor progression, are quite different between Asian and West countries. The extent of tumor progression is evaluated by the number and the size of tumors, the extent of vascular invasion, and the presence of extrahepatic metastasis. In Asian countries, in addition to the tumors within the Milan criteria, liver resection is attempted for selected advanced HCC cases outside the Milan criteria as long as the absence of extrahepatic metastasis and technically feasible [3-5]. On the other hand, in Western countries, which follow the Barcelona-Clinic Liver Cancer staging classification (BCLC staging system), have set narrow indications for liver resection [8]. For those with single nodules within $2 \mathrm{~cm}$ in size without vascular invasion or extrahepatic metastasis, liver resection is recommended. This is mainly due to the low hurdle for liver transplantation.

\section{Surgical Treatment of HCC within Milan Criteria}

For patients with HCC less than three in number and less than $3 \mathrm{~cm}$ in size or a single tumor less than $5 \mathrm{~cm}$ in size (equivalent to BCLC-A), liver resection and radiofrequency ablation (RFA) are recommended with equal weight in Asian countries [3-5]. On the other hand, in Western countries, liver resection is not recommended for patients with two or three tumors. Moreover, in cases with portal hypertension and high bilirubin levels, RFA or liver transplantation is recommended instead of liver resection [6,7]. Certainly, liver transplantation is an ideal treatment that can eliminate unrecognized sites of intrahepatic spread as well as the possibility of de novo HCC arising from the diseased parenchyma. In general, the 10-year recurrence-free survival rate after liver transplantation is around $50-70 \%$, which is extremely good compared to $30-50 \%$ for liver resection [2]. Due to severe shortage of liver graft and disease progression while on the waiting list, liver resection and transarterial chemoembolization (TACE) have been used as the second most effective treatment after transplantation. According to the nationwide survey in Japan, the five-year survival rate after liver resection for the HCC patients within the Milan criteria is about $70 \%$. Liver resection may achieve long-term survival comparable to liver transplantation if appropriate treatment against recurrent HCC and resolution of the cause of hepatitis can be performed [9,10]. In addition, recent reports from Western countries suggest the usefulness of liver resection for HCC patients within the Milan criteria for effective utilization of limited liver graft [2]. For increasing resectability with preventing posthepatectomy liver failure due to insufficient future liver remnant (FLR), portal vein embolization was performed as conventional approach [11]. As an alternative approach for FLR augmentation, associating liver partition and portal vein ligation for staged hepatectomy (ALLPS) has been popularized [12]. Most of the evidences focus on ALLPS procedure against colorectal liver metastases [13]. There are still few reports about the safety and efficacy of ALLPS for the treatment of HCC with liver cirrhosis, further studies are warranted [14-16]. On the other hand, RFA is an option for patients who cannot undergo hepatectomy. Currently, a large randomized controlled trial in Japan has shown that there is no significant difference in three-year recurrence-free survival between liver resection and RFA groups, and analysis of long-term prognosis is awaited [17]. HCC has a high recurrence rate even after curative treatment, with intrahepatic recurrence accounting for the majority of cases. The treatment strategy of intrahepatic recurrence is based on the same algorithm as for initial treatment. This means that the choice of treatment depends on the liver functional reserve and the biological features of the recurrent tumor $[18,19]$. In a comparison of surgical treatment between repeat hepatectomy 
and salvage liver transplantation, many reports show that salvage liver transplantation has a good recurrence-free survival rate; however, there is no difference in five-year survival rate between the two groups $[20,21]$. In view of the current donor shortage, repeat hepatectomy may be a useful option for recurrent HCC.

\section{Surgical Treatment of Highly Advanced HCC Outside Milan Criteria}

HCCs with vascular invasion are considered as very advanced stage, and liver resection is not recommended in Western countries. In Asian countries, all treatment options, including liver resection, are recommended as treatment options. Still, liver resection is the first consideration if liver function is preserved and technically resectable [3-5]. As for multiple HCCs, tumors outside the Milan criteria are classified as intermediate stage by the BCLC staging system, and TACE is recommended in Western countries; on the other hand, from Asian countries, the effectiveness of liver resection have been reported [22,23]. Systematic review about treatment strategy against intermediate stage HCC reported the effectiveness of liver resection in selected patients [24,25].

\subsection{Liver Resection for HCC with Portal Vein Tumor Thrombus}

The incidence of Portal vein tumor thrombus (PVTT) has been confirmed in more than $40 \%$ of HCCs and have an extremely poor prognosis with a median survival of 2.74 months without any treatment [26,27]. In addition, the extent of the disease correlates with prognosis, and the classification of PVTT proposed by the Liver cancer study group of Japan has been widely used worldwide [28,29]. The classification is as follows: Vp0, no tumor thrombus in the portal vein; $\mathrm{Vp} 1$, presence of a tumor thrombus distal to, but not in, the second-order branches of the portal vein; $\mathrm{Vp} 2$, presence of a tumor thrombus in the second-order branches of the portal vein; $\mathrm{Vp} 3$, presence of a tumor thrombus in the first-order branches of the portal vein; and $\mathrm{Vp} 4$, presence of a tumor thrombus in the main trunk of the portal vein or a portal vein branch contralateral to the primarily involved lobe (or both) [9]. Systemic therapy is recommended as standard therapy for patients with PVTT in Western countries, but in Asian countries, liver resection is usually attempted regardless of the extent of PVTT [30-32]. In 2016, Kokudo et al. reported the outcomes of 6474 HCC patients with PVTT using Japanese national registry data [28]. Of these patients, 2093 who underwent liver resection (LR) and 4381 who received other treatments (non-LR) were compared. The median survival time (MST) of the LR group was 23.2 months longer than that of the non-LR group (29.6 months vs. 9.7 months) and 12.4 months longer than the non-LR group (28.9 months vs. 16.6 months) in a propensity score-matched cohort. Subgroup analysis based on the degree of PVTT showed that only Vp4 patients did not benefit from resection. Although similar results have been reported from Asian countries, there is an urgent need to develop more appropriate selection criteria and perioperative therapy to control postoperative recurrence [33]. So far, the usefulness of HAIC, radiation therapy, etc., have been reported [34-39].

\subsection{Liver Resection for HCC with Hepatic Vein Tumor Thrombus}

Unlike HCC with PVTT, HCC with hepatic vein tumor thrombus (HVTT) accounts for only about $5 \%$ of all HCC cases [9]. HVTT is categorized as tumor thrombus in a peripheral hepatic vein, including microvascular invasion (pHVTT, Vv1), in a major hepatic vein (mHVTT, Vv2), or in the inferior vena cava (IVCTT, Vv3) according to the Japanese staging system [40]. In 2017, Kokudo et al. reported the outcomes of 1266 HCC patients with HVTT in Japan [41]. The surgical outcome for $\mathrm{p} / \mathrm{mHVTT}$ was excellent, with a MST of 53.6 months and a five-year survival rate of $44.2 \%$. In a propensity score-matched cohort, the MST of the liver resection group was 19.3 months longer than the non-liver resection group (41 months vs. 21.7 months). On the other hand, PVTT was an independent poor prognostic factor in the $\mathrm{p} / \mathrm{mHVTT}$ resection group, and the MST of patients with PVTT was 45.4 months shorter than the patients without PVTT (22.6 months vs. 68 months). Similar reports have been reported from Asian countries, and therefore they recommended 
that at least HCC patients with intrahepatic HVTT without PVTT could be suitable for liver resection [42-44]. For preventing intrahepatic recurrence, the usefulness of postoperative adjuvant TACE has been reported, and further evaluation with randomized trials are warranted [45].

On the other hand, although IVCTT accounts for only $1 \%$ of all HCC cases, the prognosis of HCC patients with IVCTT is extremely poor because of the systemic circulation of the tumor cells and fatal complications such as pulmonary embolism, heart failure, and sudden cardiac death due to occlusion of the tricuspid valve [44]. Clinically, IVCTT is classified into three types according to its anatomic location relative to the heart for surgical guidance: type I, inferior hepatic (TT in the IVC below the diaphragm); type II, superior hepatic (TT in the IVC above the diaphragm, but still outside the RA); and type III, intracardiac (TT entering the RA) [46]. Most IVCTT can be pulled downward along with retracted liver and resected from the abdominal cavity because macroscopic thrombus of HCC is less likely to invade the vascular wall. On the other hand, in the type III IVCTT, if the TT lacks mobility and clamping of RA cannot be safely performed, cardiopulmonary bypass with median sternotomy is often required [47]. In addition, in cases with IVCTT invades the vascular wall, IVC resection and reconstruction along with liver resection has been reported to be safely performed by using an artificial graft. Therefore, surgery should be performed without hesitation [48,49]. The significance of liver resection for the patients with IVCTT should be considered from the perspective of oncology and the prevention of sudden death. In the previous report by Kokudo et al., hepatic resection for IVCTT was performed in 111 patients, with a MST of 17.8 months and a three-year survival rate of $33.1 \%$, which was significantly better than the MST of 10.1 months and a three-year survival rate of $20.1 \%$ in the non-resection group (134 patients). However, in the non-resection group, there were few cases with effective systemic therapies such as Sorafenib and Atezolizumab + Bevasizumab. Therefore, careful assessmenmt with further study is needed to evaluate the oncological benefit of liver resection. IVCTT can lead to pulmonary infarction, heart failure, and sudden death due to obstruction of the tricuspid valve. Therefore, even in cases where radical resection is difficult due to the presence of distant metastasis or multiple lesions in both lobes, liver resection and thrombectomy may be useful. Matsukuma et al. reported in a multicenter study that MST did not differ between patients who had resection with curative intent (18.7 months) and those with the residual tumor in the lung only (20.7 months) [47]. Therefore, a comprehensive evaluation of the disease state is necessary to determine the treatment plan.

\subsection{Surgical Treatment of Multiple HCC}

In addition to tumor size, tumor number is a poor prognostic factor after liver resection of HCC [50]. In the BCLC staging system, all patients with multiple HCC outside the Milan criteria without distant metastasis or vascular invasion are classified as intermediate stage, and TACE is uniformly recommended. However, there are a wide variety of patients, some of whom may benefit from liver transplantation, and some may benefit from regional therapy such as liver resection or RFA compared to TACE [51-54]. In 2019, Fukami et al. reported a nationwide study of the treatment outcomes of 3246 cases of multiple HCC in Japan [10]. Among them, subgroup analysis of the 1309 patients with HCC larger than $3 \mathrm{~cm}$ in size revealed that the 90-day mortality rate in the liver resection group was extremely low at $0.57 \%$, and a five-year overall survival rate was significantly better in the liver resection group than the TACE group (53\% vs. $32.7 \%$ ). For subclassification of these heterogeneous populations, it has been reported that the combinatorial use of the number of tumors, size, tumor markers, and liver function can be useful [22,23,51,55-57].

\section{Minimally Invasive Surgery for HCC}

Laparoscopic liver resection (LLR) was first reported in 1991, and since then, LLR has rapidly spread with an increasing number of reports about its feasibility, safety, and usefulness. Today, about a quarter of all liver resections in Japan were performed laparo- 
scopically [58]. In 2014, the second International consensus conference on Laparoscopic Liver Resection (ICCLLR) was held in Japan, and laparoscopic partial liver resection for HCC located the peripheral portion of the anterolateral segments of the liver was considered as standard clinical practice [59].

The advantages of LLR can be summarized in four points: a good field of view with minimal disruption of the body wall, magnified vision, hemostasis by buffer effect of pneumoperitoneum, and preservation of portosystemic venous and lymphatic collaterals. The laparoscopic approach could provide a good field of view for surgery on the liver, which is located within the thorax without large incisions [60]. In addition, the magnification effect allows us to observe the fine vascular structures, and managing pneumoperitoneum pressure reduces bleeding from the hepatic veins, which enables more delicate surgical procedures with a dry surgical field [61]. However, if the pneumoperitoneum pressure is higher than the central venous pressure, the risk of pulmonary gas embolism increases [62]. In terms of short-term surgical outcomes, a recent meta-analysis comparing 4026 open liver resection (OLR) and 2786 LLR patients revealed that the R0 resection rate was comparable between the two groups and blood transfusion rate, hospital stay in days, 30-day mortality rate and morbidity were significantly lower in LLR compared to OLR [63]. Among the postoperative complications, superficial surgical site infections were reported to be significantly reduced in the LLR group [64]. In terms of long-term surgical outcomes, it has been reported that there may be no difference between the two groups; however, caution is required in interpretation due to the strong influence of background factors [63]. Other advantages include the possibility of reducing the frequency of postoperative complications such as ascites and liver failure by minimizing the transection of the ligament and liver mobilization [65]. In addition, postoperative adhesions are reduced after LLR, and LLR with its magnified view enables more careful dissection of adhesions strained by the pneumoperitoneum when performing repeat LLR. An additional possible advantage of repeat LLR is reported that complete adhesiolysis could be avoided when the adhesion does not affect the current operative procedure [66].

However, it is still not a well-established procedure. It is essential to determine the indication based on a learning curve and preoperative evaluation of surgical difficulty to safely perform the operation. In 2014, Ban et al. reported the Difficulty scoring system, which predicts the surgical difficulty of LLR based on five factors (tumor location, tumor size, tumor proximity to major vessels, the extent of liver resection, and liver function) $[67,68]$. After that, this difficulty scoring system was revised after discussion at the Second ICCLLR and renamed the IWATE criteria [69,70]. Although this scoring system could predict short-term surgical outcomes, the surgical difficulty assessment system is still not perfect, and various new difficulty assessment systems are even being proposed [71-74].

\section{The Impact of HCV Eradication on Surgical Outcomes for HCC}

$\mathrm{HCV}$ infection is a major risk factor for the development of HCC in Europe, the United States, and Japan, as well as a risk factor for the progression of liver dysfunction (liver fibrosis and cirrhosis) [75]. It is now clear that elimination of HCV and achievement of sustained virological response (SVR) prevents or delays the progression of fibrosis/cirrhosis, decompensation, and the incidence of primary HCC, leading to improved survival [76]. However, the true impact of SVR on surgical outcomes of HCV related HCC remained controversial. Today $\mathrm{HCV}$ can be eliminated in almost all cases, and it is necessary to clarify that at least antiviral treatment has not worsened the surgical outcomes of HCC. Therefore, in a multicenter study, we investigated the impact of SVR before and after hepatectomy on the long-term surgical outcomes of HCV-related HCC after statistically minimizing bias arising from patients' background characteristics [77]. Two hundred ninety-six patients underwent radical hepatectomy for primary HCV related HCC, of which 58 achieved SVR before hepatectomy (Pre-SVR group), 54 achieved SVR after hepatectomy, and 186 without achieving SVR (Non-SVR group). All patients in the pre-SVR group received interferon (IFN) treatment. OS and RFS were significantly better in Pre-SVR group than 
the Non-SVR group in a propensity-matched cohort. In terms of recurrence, both early intrahepatic metastases and multicentric carcinogenesis were suppressed in the SVR group. The post-SVR group also showed significantly better OS and RFS than the non-SVR group. Furthermore, histopathological evaluation using surgically resected specimens revealed that only the patients with SVR (about 30\%) had regression of liver fibrosis. There have been several similar reports, and achievement of SVR before or after hepatectomy by IFN therapy is essential for improving long-term surgical outcomes in patients with HCV-related HCC [78-81].

Currently, the majority of treatments for HCV have replaced IFN with direct-acting antivirals (DAA). As data accumulation progresses, it has become clear that DAA treatment as well as IFN treatment associated reduced risk of mortality and HCC [82]. Concern was transiently raised that DAA treatment might increase the risk of HCC recurrence after hepatectomy; however, it is now clear that HCV elimination with DAAs does not have a significant impact on the course of established HCC $[83,84]$. On the other hand, whether HCV exclusion by DAA treatment can improve the surgical outcomes of HCC still needs further investigation due to the small number of cases and short follow-up period [85].

\section{Liver Transplantation for HCC}

Liver transplantation for HCC can cure underlying cirrhosis, the origin of multicentric carcinogenesis, while removing the tumor by total hepatectomy. The Milan criteria, defined by the size and number of the tumor, is the most commonly used and accepted indication criteria for patients with HCC [86]. Subsequently, various expanded criteria based on tumor size and number have been reported with comparable long-term outcomes compared to the Milan criteria [87-90]. In addition, a combination of alfa-fetoprotein (AFP) or des-gammacarboxy prothrombin (DCP) values as factors other than tumor size and number has been reported to improve the prognostic value of transplantation compared to the Milan criteria [91-93]. Recently, new expanded criteria, the so-called "5-5-500 rule", was proposed by the Japanese Liver Transplantation Society based on a retrospective data analysis of the Japanese nationwide survey [94]. In the study of 965 living donor liver transplants for HCC, patients with nodule size $\leq 5 \mathrm{~cm}$ in diameter, nodule number $\leq 5$, and AFP value $\leq 500 \mathrm{ng} / \mathrm{mL}$ without extrahepatic disease or vascular invasion showed a $95 \%$ confidence interval of a five-year recurrence rate of $7.3 \%$ with an increase in number of eligible liver transplant candidates by 19\% compared to the Milan criteria. In 2020, the "5-5-500 rule" was accepted as inclusion criteria for liver transplantation by the Japanese Social Insurance Coverage. There have been several reports on downstaging, and relatively good results have been obtained in terms of overall survival. Still, the recurrence rate is somewhat higher than that of cases within the Milan criteria. Therefore, the search for biomarkers, such as AFP and FDG-PET values after pretreatment, that can accurately assess the indication for liver transplantation after downstaging has been actively underway [95-100].

\section{Conclusions}

We have reviewed current topics in the treatment of HCC, with a focus on surgical treatment. The importance of liver resection has increased with the widespread use of minimally invasive surgery, the advent of DAA, and the development of multidisciplinary treatment. Accordingly, a growing number of different treatment options can be customized for individual HCC patients. In the future, it is most desirable to develop uniform and flexible treatment guidelines based on new high-quality evidence so that patients can choose the optimal HCC treatment regardless of country, and, above all, further improvement of surgical outcomes for HCC is expected.

Author Contributions: Writing-review and editing, M.N.; data curation, M.N., Y.T., Y.S., H.M., S.M., M.I., N.S., S.T., T.I., and H.N. All authors have read and agreed to the published version of the manuscript.

Funding: This research received no external funding. 
Acknowledgments: We thank Takashi Yamasaki for his useful discussions.

Conflicts of Interest: The authors declare no conflict of interest.

\section{References}

1. Llovet, J.M.; Zucman-Rossi, J.; Pikarsky, E.; Sangro, B.; Schwartz, M.; Sherman, M.; Gores, G. Hepatocellular carcinoma. Nat. Rev. Dis. Primers 2016, 2, 16018-16023. [CrossRef] [PubMed]

2. Pinna, A.D.; Yang, T.; Mazzaferro, V.; De Carlis, L.; Zhou, J.; Roayaie, S.; Shen, F.; Sposito, C.; Cescon, M.; Di Sandro, S.; et al. Liver Transplantation and Hepatic Resection can Achieve Cure for Hepatocellular Carcinoma. Ann. Surg. 2018, 268, 868-875. [CrossRef] [PubMed]

3. Kokudo, N.; Takemura, N.; Hasegawa, K.; Takayama, T.; Kubo, S.; Shimada, M.; Nagano, H.; Hatano, E.; Izumi, N.; Kaneko, S.; et al. Clinical practice guidelines for hepatocellular carcinoma: The Japan Society of Hepatology 2017 (4th JSH-HCC guidelines) 2019 update. Hepatol. Res. 2019, 49, 1109-1113. [CrossRef] [PubMed]

4. Xie, D.-Y.; Ren, Z.-G.; Zhou, J.; Fan, J.; Gao, Q. Critical appraisal of Chinese 2017 guideline on the management of hepatocellular carcinoma. Hepatobiliary Surg. Nutr. 2017, 6, 387-396. [CrossRef]

5. Shiha, G.; Ibrahim, A.; Helmy, A.; Sarin, S.K.; Omata, M.; Kumar, A.; Bernstien, D.; Maruyama, H.; Saraswat, V.; Chawla, Y.; et al. Asian-Pacific Association for the Study of the Liver (APASL) consensus guidelines on invasive and non-invasive assessment of hepatic fibrosis: A 2016 update. Hepatol. Int. 2016, 11, 1-30. [CrossRef] [PubMed]

6. Marrero, J.A.; Kulik, L.M.; Sirlin, C.B.; Zhu, A.X.; Finn, R.S.; Abecassis, M.M.; Roberts, L.R.; Heimbach, J.K. Diagnosis, Staging, and Management of Hepatocellular Carcinoma: 2018 Practice Guidance by the American Association for the Study of Liver Diseases. Hepatology 2018, 68, 723-750. [CrossRef] [PubMed]

7. Galle, P.R.; Forner, A.; Llovet, J.M.; Mazzaferro, V.; Piscaglia, F.; Raoul, J.-L.; Schirmacher, P.; Vilgrain, V. EASL Clinical Practice Guidelines: Management of hepatocellular carcinoma. J. Hepatol. 2018, 69, 182-236. [CrossRef] [PubMed]

8. Llovet, J.M.; Brú, C.; Bruix, J. Prognosis of hepatocellular carcinoma: The BCLC staging classification. Semin. Liver Dis. 1999, 19, 329-338. [CrossRef] [PubMed]

9. Kudo, M.; Izumi, N.; Kubo, S.; Kokudo, N.; Sakamoto, M.; Shiina, S.; Tateishi, R.; Nakashima, O.; Murakami, T.; Matsuyama, Y.; et al. Report of the 20th Nationwide follow-up survey of primary liver cancer in Japan. Hepatol. Res. 2019, 50, 15-46. [CrossRef] [PubMed]

10. Fukami, Y.; Kaneoka, Y.; Maeda, A.; Kumada, T.; Tanaka, J.; Akita, T.; Kubo, S.; Izumi, N.; Kadoya, M.; Sakamoto, M.; et al. Liver Resection for Multiple Hepatocellular Carcinomas. Ann. Surg. 2019, 272, 145-154. [CrossRef] [PubMed]

11. Makuuchi, M.; Thai, B.L.; Takayasu, K.; Takayama, T.; Kosuge, T.; Gunvén, P.; Yamazaki, S.; Hasegawa, H.; Ozaki, H. Preoperative portal embolization to increase safety of major hepatectomy for hilar bile duct carcinoma: A preliminary report. Surgery 1990, 107, 521-527. [PubMed]

12. Schnitzbauer, A.A.; Lang, S.A.; Goessmann, H.; Nadalin, S.; Baumgart, J.; Farkas, S.A.; Fichtner-Feigl, S.; Lorf, T.; Goralcyk, A.; Hörbelt, R.; et al. Right Portal Vein Ligation Combined With In Situ Splitting Induces Rapid Left Lateral Liver Lobe Hypertrophy Enabling 2-Staged Extended Right Hepatic Resection in Small-for-Size Settings. Ann. Surg. 2012, 255, 405. [CrossRef] [PubMed]

13. Sandström, P.; Røsok, B.I.; Sparrelid, E.; Larsen, P.N.; Larsson, A.L.; Lindell, G.; Schultz, N.A.; Bjørnbeth, B.A.; Isaksson, B.; Rizell, M.; et al. ALPPS Improves Resectability Compared With Conventional Two-stage Hepatectomy in Patients With Advanced Colorectal Liver Metastasis. Ann. Surg. 2018, 267, 833-840. [CrossRef] [PubMed]

14. Zhang, J.; Huang, H.; Bian, J.; Sang, X.; Xu, Y.; Lu, X.; Zhao, H. Safety, feasibility, and efficacy of associating liver partition and portal vein ligation for staged hepatectomy in treating hepatocellular carcinoma: A systematic review. Ann. Transl. Med. 2020, 8 , 1246. [CrossRef]

15. Wang, Z.; Peng, Y.; Hu, J.; Wang, X.; Sun, H.; Sun, J.; Shi, Y.; Xiao, Y.; Ding, Z.; Yang, X.; et al. Associating Liver Partition and Portal Vein Ligation for Staged Hepatectomy for Unresectable Hepatitis B Virus-related Hepatocellular Carcinoma: A Single Center Study of 45 Patients. Ann. Surg. 2020, 271, 534-541. [CrossRef] [PubMed]

16. Chan, A.; Zhang, W.Y.; Chok, K.; Dai, J.; Ji, R.; Kwan, C.; Man, N.; Poon, R.; Lo, C.-M. ALPPS Versus Portal Vein Embolization for Hepatitis-related Hepatocellular Carcinoma. Ann. Surg. 2019. [CrossRef] [PubMed]

17. Izumi, N.; Hasegawa, K.; Nishioka, Y.; Takayama, T.; Yamanaka, N.; Kudo, M.; Shimada, M.; Inomata, M.; Kaneko, S.; Baba, H.; et al. A multicenter randomized controlled trial to evaluate the efficacy of surgery vs. radiofrequency ablation for small hepatocellular carcinoma (SURF trial). J. Clin. Oncol. 2019, 37, 4002. [CrossRef]

18. Zheng, J.; Cai, J.; Tao, L.; Kirih, M.A.; Shen, Z.; Xu, J.; Liang, X. Comparison on the efficacy and prognosis of different strategies for intrahepatic recurrent hepatocellular carcinoma: A systematic review and Bayesian network meta-analysis. Int. J. Surg. 2020, 83, 196-204. [CrossRef] [PubMed]

19. Erridge, S.; Pucher, P.H.; Markar, S.R.; Malietzis, G.; Athanasiou, T.; Darzi, A.; Sodergren, M.H.; Jiao, L.R. Meta-analysis of determinants of survival following treatment of recurrent hepatocellular carcinoma. Br. J. Surg. 2017, 104, 1433-1442. [CrossRef]

20. Wang, H.-L.; Mo, D.-C.; Zhong, J.-H.; Ma, L.; Wu, F.-X.; Xiang, B.-D.; Li, L.-Q. Systematic review of treatment strategy for recurrent hepatocellular carcinoma. Medicine 2019, 98, e14498. [CrossRef] [PubMed]

21. Lim, C.; Shinkawa, H.; Hasegawa, K.; Bhangui, P.; Salloum, C.; Gomez Gavara, C.; Lahat, E.; Omichi, K.; Arita, J.; Sakamoto, Y.; et al. Salvage liver transplantation or repeat hepatectomy for recurrent hepatocellular carcinoma: An intent-to-treat analysis. Liver Transplant. 2017, 23, 1553-1563. [CrossRef] [PubMed] 
22. Iida, H.; Kaibori, M.; Hirokawa, F.; Inoue, Y.; Ueno, M.; Matsui, K.; Ishizaki, M.; Tanaka, S.; Takemura, S.; Nomi, T.; et al. New Hepatic Resection Criteria for Intermediate-Stage Hepatocellular Carcinoma Can Improve Long-Term Survival: A Retrospective, Multicenter Collaborative Study. Asian Pac. J. Cancer Prev. 2020, 21, 2903-2911. [CrossRef] [PubMed]

23. Wada, H.; Eguchi HNoda, T.; Ogawa, H.; Yamada, D.; Tomimaru, Y.; Tomokuni, A.; Asaoka, T.; Kawamoto, K.; Gotoh, K. Selection criteria for hepatic resection in intermediate-stage (BCLC stage B) multiple hepatocellular carcinoma. Surgery 2016, 160, 1227-1235. [CrossRef] [PubMed]

24. Liang, L.; Chen, T.-H.; Li, C.; Xing, H.; Han, J.; Wang, M.-D.; Zhang, H.; Lau, W.-Y.; Wu, M.-C.; Shen, F.; et al. A systematic review comparing outcomes of surgical resection and non-surgical treatments for patients with hepatocellular carcinoma and portal vein tumor thrombus. Int. Hepato-Pancreato-Biliary Assoc. 2018, 20, 1119-1129. [CrossRef] [PubMed]

25. Glantzounis, G.K.; Paliouras, A.; Stylianidi, M.C.; Milionis, H.; Tzimas, P.; Roukos, D.; Pentheroudakis, G.; Felekouras, E. The role of liver resection in the management of intermediate and advanced stage hepatocellular carcinoma. A systematic review. Eur. J. Surg. Oncol. 2018, 44, 195-208. [CrossRef]

26. Takizawa, D.; Kakizaki, S.; Sohara, N.; Sato, K.; Takagi, H.; Arai, H.; Katakai, K.; Kojima, A.; Matsuzaki, Y.; Mori, M. Hepatocellular carcinoma with portal vein tumor thrombosis: Clinical characteristics, prognosis, and patient survival analysis. Dig. Dis. Sci. 2007, 52, 3290-3295. [CrossRef] [PubMed]

27. Sakamoto, K.; Nagano, H. Surgical treatment for advanced hepatocellular carcinoma with portal vein tumor thrombus. Hepatol. Res. 2017, 47, 957-962. [CrossRef] [PubMed]

28. Kokudo, T.; Hasegawa, K.; Matsuyama, Y.; Takayama, T.; Izumi, N.; Kadoya, M.; Kudo, M.; Ku, Y.; Sakamoto, M.; Nakashima, O.; et al. Survival benefit of liver resection for hepatocellular carcinoma associated with portal vein invasion. J. Hepatol. 2016, 65, 938-943. [CrossRef] [PubMed]

29. Kuo, Y.-H.; Wu, I.-P.; Wang, J.-H.; Hung, C.-H.; Rau, K.-M.; Chen, C.-H.; Kee, K.-M.; Hu, T.-H.; Lu, S.-N. The outcome of sorafenib monotherapy on hepatocellular carcinoma with portal vein tumor thrombosis. Investig. New Drugs 2018, 36, 307-314. [CrossRef]

30. Finn, R.S.; Qin, S.; Ikeda, M.; Galle, P.R.; Ducreux, M.; Kim, T.-Y.; Kudo, M.; Breder, V.; Merle, P.; Kaseb, A.O.; et al. Atezolizumab plus Bevacizumab in Unresectable Hepatocellular Carcinoma. N. Engl. J. Med. 2020, 382, 1894-1905. [CrossRef] [PubMed]

31. Bruix, J.; Raoul, J.-L.; Sherman, M.; Mazzaferro, V.; Bolondi, L.; Craxì, A.; Galle, P.R.; Santoro, A.; Beaugrand, M.; Sangiovanni, A.; et al. Efficacy and safety of sorafenib in patients with advanced hepatocellular carcinoma: Subanalyses of a phase III trial. J. Hepatol. 2012, 57, 821-829. [CrossRef]

32. Llovet, J.M.; Ricci, S.; Mazzaferro, V.; Hilgard, P.; Gane, E.; Blanc, J.-F.; de Oliveira, A.C.; Santoro, A.; Raoul, J.-L.; Forner, A.; et al. Sorafenib in advanced hepatocellular carcinoma. N. Engl. J. Med. 2008, 359, 378-390. [CrossRef] [PubMed]

33. Zhang, X.P.; Gao, Y.Z.; Chen, Z.H.; Chen, M.-S.; Li, L.-Q.; Wen, T.-F.; Xu, L.; Wang, K.; Chai, Z.T.; Guo, W.X.; et al. An Eastern Hepatobiliary Surgery Hospital/Portal Vein Tumor Thrombus Scoring System as an Aid to Decision Making on Hepatectomy for Hepatocellular Carcinoma Patients With Portal Vein Tumor Thrombus: A Multicenter Study. Hepatology 2019, 69, $2076-2090$. [CrossRef] [PubMed]

34. Wei, X.; Jiang, Y.; Zhang, X.; Feng, S.; Zhou, B.; Ye, X.; Xing, H.; Xu, Y.; Shi, J.; Guo, W.; et al. Neoadjuvant Three-Dimensional Conformal Radiotherapy for Resectable Hepatocellular Carcinoma With Portal Vein Tumor Thrombus: A Randomized, OpenLabel, Multicenter Controlled Study. J. Clin. Oncol. 2019, 37, 2141-2151. [CrossRef] [PubMed]

35. Moran, A.; Ramos, L.F.; Picado, O.; Pendola, F.; Sleeman, D.; Dudeja, V.; Merchant, N.; Yakoub, D. Hepatocellular carcinoma: Resection with adjuvant hepatic artery infusion therapy vs resection alone. A systematic review and meta-analysis. J. Surg. Oncol. 2018, 61, 61-69. [CrossRef] [PubMed]

36. Hatano, E.; Uemoto, S.; Yamaue, H.; Yamamoto, M.; the Japanese Society of Hepato-Biliary-Pancreatic Surgery. Significance of hepatic resection and adjuvant hepatic arterial infusion chemotherapy for hepatocellular carcinoma with portal vein tumor thrombus in the first branch of portal vein and the main portal trunk: A project study for hepatic surgery of the Jap. J. Hepatobiliary Pancreat Sci. 2018, 25, 395-402. [CrossRef] [PubMed]

37. Nagano, H.; Obi, S.; Hatano, E.; Kaneko, S.; Kanai, F.; Omata, M.; Tsuji, A.; Itamoto, T.; Yamamoto, K.; Tanaka, M. Multicenter, randomized, controlled trial of S-1 monotherapy versus S-1 and interferon- $\alpha$ combination therapy for hepatocellular carcinoma with extrahepatic metastases. Hepatol. Res. 2018, 48, 717-726. [CrossRef] [PubMed]

38. Nagano, H.; Miyamoto, A.; Wada, H.; Ota, H.; Marubashi, S.; Takeda, Y.; Dono, K.; Umeshita, K.; Sakon, M.; Monden, M. Interferon-alpha and 5-fluorouracil combination therapy after palliative hepatic resection in patients with advanced hepatocellular carcinoma, portal venous tumor thrombus in the major trunk, and multiple nodules. Cancer 2007, 110, 2493-2501. [CrossRef]

39. Nagano, H.; Sakon, M.; Eguchi, H.; Kondo, M.; Yamamoto, T.; Ota, H.; Nakamura, M.; Wada, H.; Damdinsuren, B.; Marubashi, S. Hepatic resection followed by IFN-alpha and 5-FU for advanced hepatocellular carcinoma with tumor thrombus in the major portal branch. Hepato-Gastroenterol. 2007, 54, 172-179.

40. Kudo, M.; Izumi, N.; Kokudo, N.; Matsui, O.; Sakamoto, M.; Nakashima, O.; Kojiro, M.; Makuuchi, M. Management of hepatocellular carcinoma in Japan: Consensus-Based Clinical Practice Guidelines proposed by the Japan Society of Hepatology (JSH) 2010 updated version. Dig. Dis. 2011, 29, 339-364. [CrossRef] [PubMed]

41. Kokudo, T.; Hasegawa, K.; Matsuyama, Y.; Takayama, T.; Izumi, N.; Kadoya, M. Liver resection for hepatocellular carcinoma associated with hepatic vein invasion: A Japanese nationwide survey. Hepatology 2017, 66, 510-517. [CrossRef] [PubMed] 
42. Zhang, X.P.; Wang, K.; Gao, Y.Z.; Wei, X.B.; Lu, C.D.; Chai, Z.T.; Zhen, Z.J.; Li, J.; Yang, D.H.; Zhou, D.; et al. Prognostic model for identifying candidates for hepatectomy among patients with hepatocellular carcinoma and hepatic vein invasion. Br. J. Surg. 2020, 107, 865-877. [CrossRef] [PubMed]

43. Chen, Z.H.; Zhang, X.P.; Wang, K.; Sun, J.X.; Chai, Z.T.; Yang, Y.; Guo, W.X.; Shi, J.; Lau, W.-Y.; Cheng, S.Q. Liver resection versus transcatheter arterial chemoembolization for the treatment of patients with hepatocellular carcinoma and hepatic vein or inferior vena cava tumor thrombus: A propensity score matching analysis. Hepatol. Res. 2018, 49, 441-452. [CrossRef] [PubMed]

44. Sakamoto, K.; Nagano, H. Outcomes of surgery for hepatocellular carcinoma with tumor thrombus in the inferior vena cava or right atrium. Surg. Today 2018, 48, 819-824. [CrossRef] [PubMed]

45. Zhang, X.P.; Liu, Y.-C.; Chen, Z.H.; Sun, J.X.; Wang, K.; Chai, Z.T.; Shi, J.; Guo, W.X.; Wu, M.-C.; Lau, W.-Y.; et al. Postoperative Adjuvant Transarterial Chemoembolization Improves Outcomes of Hepatocellular Carcinoma Associated with Hepatic Vein Invasion: A Propensity Score Matching Analysis. Ann. Surg. Oncol. 2019, 26, 1465-1473. [CrossRef]

46. Li, A.-J.; Zhou, W.-P.; Lin, C.; Lang, X.-L.; Wang, Z.-G.; Yang, X.-Y.; Tang, Q.-H.; Tao, R.; Wu, M.-C. Surgical treatment of hepatocellular carcinoma with inferior vena cava tumor thrombus: A new classification for surgical guidance. Hepatobiliary Pancreat. Dis. Int. 2013, 12, 263-269. [CrossRef]

47. Matsukuma, S.; Eguchi, H.; Wada, H.; Noda, T.; Shindo, Y.; Tokumitsu, Y.; Matsui, H.; Takahashi, H.; Kobayashi, S.; Nagano, H. Liver resection with thrombectomy for patients with hepatocellular carcinoma and tumour thrombus in the inferior vena cava or right atrium. BJS Open 2020, 4, 241-251. [CrossRef]

48. Tomimaru, Y.; Eguchi, H.; Wada, H.; Doki, Y.; Mori, M.; Nagano, H. Surgical Outcomes of Liver Resection Combined with Inferior Vena Cava Resection and Reconstruction with Artificial Vascular Graft. Dig. Surg. 2019, 36, 502-508. [CrossRef] [PubMed]

49. Tomimaru, Y.; Eguchi, H.; Wada, H.; Doki, Y.; Mori, M.; Nagano, H. Liver resection combined with inferior vena cava resection and reconstruction using artificial vascular graft: A literature review. Ann. Gastroenterol. Surg. 2018, 2, 182-186. [CrossRef] [PubMed]

50. Tokumitsu, Y.; Shindo, Y.; Matsui, H.; Matsukuma, S.; Nakajima, M.; Suzuki, N.; Takeda, S.; Wada, H.; Kobayashi, S.; Eguchi, H.; et al. Utility of scoring systems combining the product of tumor number and size with liver function for predicting the prognosis of patients with hepatocellular carcinoma after hepatectomy. Oncol. Lett. 2019, 18, 3903-3913. [CrossRef] [PubMed]

51. Hyun, M.H.; Lee, Y.-S.; Kim, J.H.; Lee, C.U.; Jung, Y.K.; Seo, Y.S.; Yim, H.J.; Yeon, J.E.; Byun, K.S. Hepatic resection compared to chemoembolization in intermediate- to advanced-stage hepatocellular carcinoma: A meta-analysis of high-quality studies. Hepatology 2018, 68, 977-993. [CrossRef]

52. Kim, H.; Ahn, S.W.; Hong, S.K.; Yoon, K.C.; Kim, H.S.; Choi, Y.R.; Lee, H.W.; Yi, N.J.; Lee, K.W.; Suh, K.S. Survival benefit of liver resection for Barcelona Clinic Liver Cancer stage B hepatocellular carcinoma. Br. J. Surg. 2017, 104, 1045-1052. [CrossRef] [PubMed]

53. Zhong, J.-H.; Ke, Y.; Gong, W.-F.; Xiang, B.-D.; Ma, L.; Ye, X.-P.; Peng, T.; Xie, G.-S.; Li, L.-Q. Hepatic Resection Associated With Good Survival for Selected Patients With Intermediate and Advanced-Stage Hepatocellular Carcinoma. Ann. Surg. 2014, 260, 329-340. [CrossRef] [PubMed]

54. Yin, L.; Li, H.; Li, A.-J.; Lau, W.-Y.; Pan, Z.-Y.; Lai, E.C.H.; Wu, M.-C.; Zhou, W.-P. Partial hepatectomy vs. transcatheter arterial chemoembolization for resectable multiple hepatocellular carcinoma beyond Milan criteria: A RCT. J. Hepatol. 2014, 61, 82-88. [CrossRef] [PubMed]

55. Matsukuma, S.; Sakamoto, K.; Tokuhisa, Y.; Tokumitsu, Y.; Matsui, H.; Kanekiyo, S.; Tomochika, S.; Iida, M.; Suzuki, N.; Takeda, S.; et al. Outcomes following liver resection for multinodular Barcelona Clinic Liver Cancer-B hepatocellular carcinoma. Oncol. Lett. 2018, 1-10. [CrossRef]

56. Kamiyama, T.; Orimo, T.; Wakayama, K.; Shimada, S.; Nagatsu, A.; Yokoo, H.; Kamachi, H.; Yamashita, K.; Shimamura, T.; Taketomi, A. Survival outcomes of hepatectomy for stage B Hepatocellular carcinoma in the BCLC classification. World J. Surg. Oncol. 2017, 15, 1-8. [CrossRef]

57. Tada, T.; Kumada, T.; Toyoda, H.; Tsuji, K.; Hiraoka, A.; Itobayashi, E.; Nouso, K.; Kariyama, K.; Ishikawa, T.; Hirooka, M.; et al. Role of hepatic resection in patients with intermediate-stage hepatocellular carcinoma: A multicenter study from Japan. Cancer Sci. 2017, 108, 1414-1420. [CrossRef] [PubMed]

58. Ban, D.; Tanabe, M.; Kumamaru, H.; Nitta, H.; Otsuka, Y.; Miyata, H.; Kakeji, Y.; Kitagawa, Y.; Kaneko, H.; Wakabayashi, G.; et al. Safe Dissemination of Laparoscopic Liver Resection in 27,146 Cases Between 2011 and 2017 From the National Clinical Database of Japan. Ann. Surg. 2020. [CrossRef] [PubMed]

59. Cho, J.Y.; Han, H.-S.; Wakabayashi, G.; Soubrane, O.; Geller, D.; O'Rourke, N.; Buell, J.; Cherqui, D. Practical guidelines for performing laparoscopic liver resection based on the second international laparoscopic liver consensus conference. Surg. Oncol. 2018, 27, A5-A9. [CrossRef] [PubMed]

60. Zheng, H.; Huang, S.G.; Qin, S.M.; Xiang, F. Comparison of laparoscopic versus open liver resection for lesions located in posterosuperior segments: A meta-analysis of short-term and oncological outcomes. Surg. Endosc. 2019, 33, 3910-3918. [CrossRef]

61. Morise, Z. Developments and perspectives of laparoscopic liver resection in the treatment of hepatocellular carcinoma. Surg. Today 2019, 49, 649-655. [CrossRef] [PubMed]

62. Kobayashi, S.; Honda, G.; Kurata, M.; Tadano, S.; Sakamoto, K.; Okuda, Y.; Abe, K. An Experimental Study on the Relationship Among Airway Pressure, Pneumoperitoneum Pressure, and Central Venous Pressure in Pure Laparoscopic Hepatectomy. Ann. Surg. 2016, 263, 1159-1163. [CrossRef] [PubMed] 
63. Meng, X.; Xu, Y.; Pan, Y.; Lu, S.; Duan, W. Open versus laparoscopic hepatic resection for hepatocellular carcinoma: A systematic review and meta-analysis. Surg. Endosc. 2019, 33, 2396-2418. [CrossRef] [PubMed]

64. Matsukuma, S.; Tokumitsu, Y.; Nakagami, Y.; Shindo, Y.; Matsui, H.; Nakajima, M.; Iida, M.; Suzuki, N.; Takeda, S.; Nagano, H. Laparoscopic resection reduces superficial surgical site infection in liver surgery. Surg. Endosc. 2020, 218, 1-11. [CrossRef]

65. Troisi, R.I.; Berardi, G.; Morise, Z.; Cipriani, F.; Ariizumi, S.; Sposito, C.; Panetta, V.; Simonelli, I.; Kim, S.; Goh, B.K.P.; et al. Laparoscopic and open liver resection for hepatocellular carcinoma with Child-Pugh B cirrhosis: Multicentre propensity score-matched study. Br. J. Surg. 2021, 136. [CrossRef]

66. Morise, Z.; Aldrighetti, L.; Belli, G.; Ratti, F.; Belli, A.; Cherqui, D.; Tanabe, M.; Wakabayashi, G.; Cheung, T.T.; Lo, C.M.; et al. Laparoscopic repeat liver resection for hepatocellular carcinoma: A multicentre propensity score-based study. Br. J. Surg. 2020, 107, 889-895. [CrossRef] [PubMed]

67. Tanaka, S.; Kubo, S.; Kanazawa, A.; Takeda, Y.; Hirokawa, F.; Nitta, H.; Nakajima, T.; Kaizu, T.; Kaneko, H.; Wakabayashi, G. Validation of a Difficulty Scoring System for Laparoscopic Liver Resection: A Multicenter Analysis by the Endoscopic Liver Surgery Study Group in Japan. J. Am. Coll. Surg. 2017, 225, 249-258. [CrossRef] [PubMed]

68. Ban, D.; Tanabe, M.; Ito, H.; Otsuka, Y.; Nitta, H.; Abe, Y.; Hasegawa, Y.; Katagiri, T.; Takagi, C.; Itano, O. A novel difficulty scoring system for laparoscopic liver resection. J. Hepatobiliary Pancreat Sci. 2014, 21, 745-753. [CrossRef] [PubMed]

69. Tanaka, S.; Kawaguchi, Y.; Kubo, S.; Kanazawa, A.; Takeda, A.; Hirokawa, F.; Nitta, H.; Nakajima, T.; Kaizu, T.; Kaibori, M.; et al. Validation of index-based IWATE criteria as an improved difficulty scoring system for laparoscopic liver resection. Surgery 2018, 1-10. [CrossRef] [PubMed]

70. Wakabayashi, G. What has changed after the Morioka consensus conference 2014 on laparoscopic liver resection? Hepatobiliary Surg. Nutr. 2016, 5, 281-289. [CrossRef] [PubMed]

71. Russolillo, N.; Maina, C.; Fleres, F.; Langella, S.; Tesoriere Lo, R.; Ferrero, A. Comparison and validation of three difficulty scoring systems in laparoscopic liver surgery: A retrospective analysis on 300 cases. Surg. Endosc. 2020, 34, 5484-5494. [CrossRef] [PubMed]

72. Halls, M.C.; Berardi, G.; Cipriani, F.; Barkhatov, L.; Lainas, P.; Harris, S.; D'Hondt, M.; Rotellar, F.; Dagher, I.; Aldrighetti, L.; et al. Development and validation of a difficulty score to predict intraoperative complications during laparoscopic liver resection. Br. J. Surg. 2018, 105, 1182-1191. [CrossRef] [PubMed]

73. Kawaguchi, Y.; Fuks, D.; Kokudo, N.; Gayet, B. Difficulty of Laparoscopic Liver Resection. Ann. Surg. 2018, 267, 13-17. [CrossRef] [PubMed]

74. Hasegawa, Y.; Wakabayashi, G.; Nitta, H.; Takahara, T.; Katagiri, H.; Umemura, A.; Makabe, K.; Sasaki, A. A novel model for prediction of pure laparoscopic liver resection surgical difficulty. Surg. Endosc. 2017, 31, 5356-5363. [CrossRef] [PubMed]

75. Ban, D.; Ogura, T.; Akahoshi, K.; Tanabe, M. Current topics in the surgical treatments for hepatocellular carcinoma. Ann. Gastroenterol. Surg. 2018, 2, 137-146. [CrossRef] [PubMed]

76. Nahon, P.; Bourcier, V.; Layese, R.; Audureau, E.; Cagnot, C.; Marcellin, P.; Guyader, D.; Fontaine, H.; Larrey, D.; De Lédinghen, V.; et al. Eradication of Hepatitis C Virus Infection in Patients With Cirrhosis Reduces Risk of Liver and Non-Liver Complications. Gastroenterology 2017, 152, 142-156. [CrossRef] [PubMed]

77. Nakajima, M.; Kobayashi, S.; Wada, H.; Tomokuni, A.; Takahashi, H.; Noda, T.; Matsui, H.; Matsukuma, S.; Kanekiyo, S.; Shindo, Y.; et al. Viral elimination is essential for improving surgical outcomes of hepatitis $\mathrm{C}$ virus-related hepatocellular carcinoma: Multicenter retrospective analysis. Ann. Gastroenterol. Surg. 2020, 2, 137. [CrossRef]

78. Okamura, Y.; Sugiura, T.; Ito, T.; Yamamoto, Y.; Ashida, R.; Ohgi, K.; Uesaka, K. The Achievement of a Sustained Virological Response Either Before or After Hepatectomy Improves the Prognosis of Patients with Primary Hepatitis C Virus-Related Hepatocellular Carcinoma. Ann. Surg. Oncol. 2019, 26, 4566-4575. [CrossRef] [PubMed]

79. Shinkawa, H.; Tanaka, S.; Takemura, S.; Ito, T.; Aota, T.; Koda, M.; Miyazaki, T.; Yamamoto, T.; Kubo, S. Obesity and recurrencefree survival in patients with hepatocellular carcinoma after achieving sustained virological response to interferon therapy for chronic hepatitis C. Ann. Gastroenterol. Surg. 2018, 2, 319-326. [CrossRef]

80. Shinkawa, H.; Hasegawa, K.; Arita, J.; Akamatsu, N.; Kaneko, J.; Sakamoto, Y.; Kokudo, N. Impact of Sustained Virological Response to Interferon Therapy on Recurrence of Hepatitis C Virus-Related Hepatocellular Carcinoma. Ann. Surg. Oncol. 2017, 24, 3196-3202. [CrossRef] [PubMed]

81. Okimoto, S.; Kobayashi, T.; Kuroda, S.; Ishiyama, K.; Ide, K.; Ohira, M.; Tahara, H.; Shimizu, S.; Iwako, H.; Hamaoka, M.; et al. Prediction of recurrence following hepatectomy in patients with hepatitis $\mathrm{C}$ virus infection-related hepatocellular carcinoma who achieved a sustained virological response. Hepatol. Res. 2017, 47, 1186-1195. [CrossRef] [PubMed]

82. Carrat, F.; Fontaine, H.; Dorival, C.; Simony, M.; Diallo, A.; Hézode, C.; De Lédinghen, V.; Larrey, D.; Haour, G.; Bronowicki, J.-P.; et al. Clinical outcomes in patients with chronic hepatitis $\mathrm{C}$ after direct-acting antiviral treatment: A prospective cohort study. Lancet 2019, 393, 1453-1464. [CrossRef]

83. Singal, A.G.; Rich, N.E.; Mehta, N.; Branch, A.D.; Pillai, A.; Hoteit, M.; Volk, M.; Odewole, M.; Scaglione, S.; Guy, J.; et al. Direct-Acting Antiviral Therapy for Hepatitis C Virus Infection Is Associated With Increased Survival in Patients With a History of Hepatocellular Carcinoma. Gastroenterology 2019, 157, 1253-1263. [CrossRef] [PubMed]

84. Reig, M.; Mariño, Z.; Perelló, C.; Iñarrairaegui, M.; Ribeiro, A.; Lens, S.; Díaz, A.; Vilana, R.; Darnell, A.; Varela, M.; et al. Unexpected early tumor recurrence in patients with hepatitis $C$ virus -related hepatocellular carcinoma undergoing interferonfree therapy: A note of caution. J. Hepatol. 2016, 1-34. [CrossRef] 
85. Nagata, H.; Nakagawa, M.; Asahina, Y.; Sato, A.; Asano, Y.; Tsunoda, T.; Miyoshi, M.; Kaneko, S.; Otani, S.; Kawai-Kitahata, F.; et al. Effect of interferon-based and -free therapy on early occurrence and recurrence of hepatocellular carcinoma in chronic hepatitis C. J. Hepatol. 2017, 67, 933-939. [CrossRef] [PubMed]

86. Mazzaferro, V.; Regalia, E.; Doci, R.; Andreola, S.; Pulvirenti, A.; Bozzetti, F.; Montalto, F.; Ammatuna, M.; Morabito, A.; Gennari, L. Liver transplantation for the treatment of small hepatocellular carcinomas in patients with cirrhosis. N. Engl. J. Med. 1996, 334, 693-699. [CrossRef] [PubMed]

87. Guiteau, J.J.; Cotton, R.T.; Washburn, W.K.; Harper, A.; O’Mahony, C.A.; Sebastian, A.; Cheng, S.; Klintmalm, G.; Ghobrial, M.; Halff, G.; et al. An Early Regional Experience with Expansion of Milan Criteria for Liver Transplant Recipients. Am. J. Transplant. 2010, 10, 2092-2098. [CrossRef] [PubMed]

88. Mazzaferro, V.; Llovet, J.M.; Miceli, R.; Bhoori, S.; Schiavo, M.; Mariani, L.; Camerini, T.; Roayaie, S.; Schwartz, M.E.; Grazi, G.L.; et al. Predicting survival after liver transplantation in patients with hepatocellular carcinoma beyond the Milan criteria: A retrospective, exploratory analysis. Lancet Oncol. 2009, 10, 35-43. [CrossRef]

89. Yao, F.Y.; Xiao, L.; Bass, N.M.; Kerlan, R.; Ascher, N.L.; Roberts, J.P. Liver Transplantation for Hepatocellular Carcinoma: Validation of the UCSF-Expanded Criteria Based on Preoperative Imaging. Am. J. Transplant. 2007, 7, 2587-2596. [CrossRef]

90. Sugawara, Y.; Tamura, S.; Makuuchi, M. Living donor liver transplantation for hepatocellular carcinoma: Tokyo University series. Dig. Dis. 2007, 25, 310-312. [CrossRef]

91. Duvoux, C.; Roudot-Thoraval, F.; Decaens, T.; Pessione, F.; Badran, H.; Piardi, T.; Francoz, C.; Compagnon, P.; Vanlemmens, C.; Dumortier, J.; et al. Liver transplantation for hepatocellular carcinoma: A model including $\alpha$-fetoprotein improves the performance of Milan criteria. Gastroenterology 2012, 143, 986-94.e3. [CrossRef]

92. Toso, C.; Trotter, J.; Wei, A.; Bigam, D.L.; Shah, S.; Lancaster, J.; Grant, D.R.; Greig, P.D.; Shapiro, A.M.J.; Kneteman, N.M. Total tumor volume predicts risk of recurrence following liver transplantation in patients with hepatocellular carcinoma. Liver Transplant. 2008, 14, 1107-1115. [CrossRef] [PubMed]

93. Takada, Y.; Ito, T.; Ueda, M.; Sakamoto, S.; Haga, H.; Maetani, Y.; Ogawa, K.; Ogura, Y.; Oike, F.; Egawa, H.; et al. Living donor liver transplantation for patients with HCC exceeding the Milan criteria: A proposal of expanded criteria. Dig. Dis. 2007, 25, 299-302. [CrossRef] [PubMed]

94. Shimamura, T.; Akamatsu, N.; Fujiyoshi, M.; Kawaguchi, A.; Morita, S.; Kawasaki, S.; Uemoto, S.; Kokudo, N.; Hasegawa, K.; Ohdan, H.; et al. Expanded living-donor liver transplantation criteria for patients with hepatocellular carcinoma based on the Japanese nationwide survey: The 5-5-500 rule-A retrospective study. Transpl. Int 2019, 32, 356-368. [CrossRef]

95. Mehta, N.; Dodge, J.L.; Grab, J.D.; Yao, F.Y. National Experience on Down-Staging of Hepatocellular Carcinoma Before Liver Transplant: Influence of Tumor Burden, Alpha-Fetoprotein, and Wait Time. Hepatology 2019, 71, 943-954. [CrossRef]

96. Lee, S.M.; Kim, H.S.; Lee, S.; Lee, J.W. Emerging role of 18F-fluorodeoxyglucose positron emission tomography for guiding management of hepatocellular carcinoma. World J. Gastroenterol. WJG 2019, 25, 1289-1306. [CrossRef]

97. Ravaioli, M.; Odaldi, F.; Cucchetti, A.; Trevisani, F.; Piscaglia, F.; De Pace, V.; Bertuzzo, V.R.; Neri, F.; Golfieri, R. Long term results of down-staging and liver transplantation for patients with hepatocellular carcinoma beyond the conventional criteria. Sci. Rep. 2019, 9, 1-9. [CrossRef]

98. Mehta, N.; Guy, J.; Frenette, C.T.; Dodge, J.L.; Osorio, R.W.; Minteer, W.B.; Roberts, J.P.; Yao, F.Y. Excellent Outcomes of Liver Transplantation Following Down-Staging of Hepatocellular Carcinoma to Within Milan Criteria: A Multicenter Study. Clin. Gastroenterol. Hepatol. 2018, 16, 955-964. [CrossRef]

99. Llovet, J.M.; Pavel, M.; Rimola, J.; Diaz, M.A.; Colmenero, J.; Saavedra-Perez, D.; Fondevila, C.; Ayuso, C.; Fuster, J.; Ginès, P.; et al. Pilot study of living donor liver transplantation for patients with hepatocellular carcinoma exceeding Milan Criteria (Barcelona Clinic Liver Cancer extended criteria). Liver Transplant. 2018, 24, 369-379. [CrossRef] [PubMed]

100. Yao, F.Y.; Mehta, N.; Flemming, J.; Dodge, J.; Hameed, B.; Fix, O.; Hirose, R.; Fidelman, N.; Kerlan, R.K., Jr.; Roberts, J.P. Downstaging of hepatocellular cancer before liver transplant: Long-term outcome compared to tumors within Milan criteria. Hepatology 2015, 61, 1968-1977. [CrossRef] 